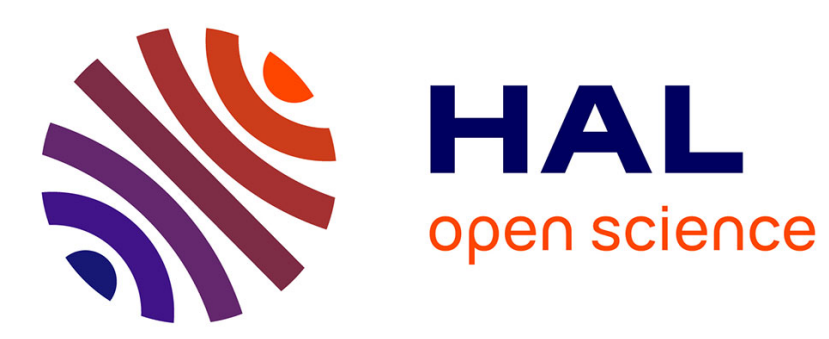

\title{
Equity and efficiency of compulsory schooling: is it necessary to choose and if so on what grounds?
}

Denis Meuret

\section{To cite this version:}

Denis Meuret. Equity and efficiency of compulsory schooling: is it necessary to choose and if so on what grounds?. Prospects, 2006, XXXVI (4), pp.389-410. 10.1007/s11125-006-9004-8 . halshs00176160

\section{HAL Id: halshs-00176160 \\ https://shs.hal.science/halshs-00176160}

Submitted on 10 Jun 2021

HAL is a multi-disciplinary open access archive for the deposit and dissemination of scientific research documents, whether they are published or not. The documents may come from teaching and research institutions in France or abroad, or from public or private research centers.
L'archive ouverte pluridisciplinaire HAL, est destinée au dépôt et à la diffusion de documents scientifiques de niveau recherche, publiés ou non, émanant des établissements d'enseignement et de recherche français ou étrangers, des laboratoires publics ou privés. 


\title{
E Q U I T Y A N D EF F I I E N C Y O F C O M P U L S R Y S C H O O ING :
}

\section{IS IT NECESSAR TO CHOOSE A N IF SO ON WHAT GROUND?}

Denis Meuret

IREDU-CNRS, Université de Bourgogne

Article publié dans Prospects, vol.36, n4, Dec.2006, pp.389-409

\begin{abstract}
:
The last system of international indicators on which Norberto Bottani ${ }^{1}$ and I worked, together with other colleagues, concerned the equity of education systems in European countries (GERESE$\left.{ }^{2}, 2005,2003\right)$. I would like to take this opportunity to reply to two objections raised regarding that work. The first is that, as an objective, equity takes second place to efficiency. For example, the low dispersion of literacy scores among Italian students is immediately overridden, in the minds of the country's auditors, by their low average score, on the basis of the argument that a health system that cures a given illness better for rich patients than for poor patients is preferable to one that fails to cure it at all, if only because there is a hope in the former case that the benefits of the cure may later be extended to all. Does the same go for education?
\end{abstract}


The second objection is that the equity of an education system has little to do with (or is of little importance compared with) the equity of society in general. What is the point of giving immigrants better education if there is no work for them anyway? And is it worth offering equal access to diplomas if the diplomas are thereby socially depreciated?

These two criticisms may be combined in a single view, which was expressed by one of the speakers at the Congress of the American Educational Research Association (AERA) in April 2005: "Is an efficient education system coupled with a good Welfare State not preferable to an equitable but inefficient education system?"

The educational policies that are rejected in the name of efficiency are those which eliminate the differences between weak and strong students, by doing away with repetition, marks, streaming, rewards for accomplishments and mass admission to training previously reserved for the few.

Other policies rejected for the same reason include those that attempt to bring all students up to a minimum standard, as was tried in France with the "common core" policy advocated by the Thélot Commission. The SNES (Syndicat National des Enseignements de Second degré - National Union of Secondary School Teaching), for instance, objects that this common core "excludes the ingredients of a common culture that should be instilled in all students". It is, in other words, inadequate and this inadequacy is blameworthy because the skills which the common core should and does not incorporate are in fact currently mastered at least by a minority. What the SNES is afraid of is that the effort to inculcate what are considered to be "limited and utilitarian" skills in the weakest pupils, who are also usually the most underprivileged, entails forfeiting the possibility of offering more "cultural" skills to others, in other words, that equity should be placed before efficiency.

These are the objections to which I would like to reply, first from a theoretical point of view, and then in more detail from an empirical standpoint, on the basis of several criteria of efficiency and equity, and by referring - how could I do otherwise in a tribute to Norberto? - to international comparisons. To start with, however, I should like to introduce the criteria and approach adopted in this paper.

\section{Efficiency versus equity - the theory}

It is not often that an equity-oriented policy is rejected on the grounds that a different concept of equity ${ }^{3}$ is preferred and even less so on the grounds that equity does not matter. More frequently the view expressed (Hirschman, 1991) is that equitable policies are either useless (because they will not improve the educational standards of the weakest or poorest), or counterproductive (because they will adversely affect the long-term interests of their intended beneficiaries), or even catastrophic (because they will lead to a general breakdown). In all three cases, the underlying sticking point is efficiency, internal efficiency in the first case, external efficiency in the second, and probably both in the third.

One answer, which I would consider nominalistic, consists in saying that equity is part of efficiency because certain forms of equality are objectives of education systems to the same extent as the maximization of skills, so that, on the assumption that efficiency is 
defined as the achievement of set objectives, an efficient education system must be both "efficient" and "equitable". But this does not really answer our question, which is whether there is opposition between equality and skill maximization, and, if so, to which should priority be given.

The answer I would like to suggest is taken from John Rawls' A theory of justice, namely that in education equity takes precedence over efficiency.

Generally speaking, the Theory of Justice gives priority to political liberties over equality of opportunities and resolves the conflict between equity and efficiency through the Difference Principle: given two conditions that are similar from the point of view of political liberties and equality of opportunities, priority must be given to the one where the least well-off may lay claim to as many "primary goods" as are available (including wealth, power, and "the social bases of self-respect").

- The importance given to the Difference Principle, however, in the theory is limited by the fact that no allowance or grant can replace the self-fulfilment procured by responsible, independent work. This is why fair equality of opportunity is not restricted to the sphere of education. Fair equality of opportunity in education cancelled out by a segregated or unequal operation of the labour market is worthless.

- Fair equality of opportunity takes lexical priority over the Difference Principle: inequality of opportunities cannot be justified on the grounds that the offspring of wealthy parents once educated will work for the benefit of the leastadvantaged.

The fact that Rawls considers education as a means and not an end has two implications:

- He draws a distinction between the Difference Principle and the principle of compensation. Life, he says, is not a handicap race where justice consists in rewarding every person's merits: therefore "favouring the more gifted is justified provided that it improves the long-term expectations of the least well-off". For Rawls, "natural" inequalities are no more justified than socially derived inequalities, but, precisely because they are natural, they must obey other rules and must be applied in accordance with the Difference Principle. This principle cannot serve to justify giving more education to the rich, but it may justify giving more to the most talented. This is because Rawls believes that the talents of individuals are a common good, which Nozick denies.

- On the other hand, Rawls does not admit in his reasoning that the most talented should be favoured or that a degree of inequality of opportunity should be considered acceptable simply for the sake of the greater internal efficiency of education. This is based on two reasons, which need to be seen together. The first is that fair equality of opportunity takes precedence over the Difference Principle, and the second that inequalities between individuals (here in terms of education) are justified only in the context of institutions such that the activity of the most educated will increase the quantity of "primary social goods" available to the least well-off. Any distribution of education that favours the student elite, or even average students, to the detriment of equal opportunity of access to desirable social positions or to the detriment of the quantity of primary social goods available to the least well-off is not compatible with the Theory of Justice.

The problem is not so simple, however, since "social primary goods" include goods that are differently related to education. Let us take two cases with the same fair equality of opportunity and let us consider two "social primary goods", the social bases of 
self-respect and wealth. While education as such is an essential component of the "social bases of self-respect", for instance in a society which is strongly attached to its schooling system, according to the Difference Principle social inequalities (including educational inequalities) are justified only insofar as they serve to maximize the educational standard of the weakest. On the other hand, in the case of wealth, the Difference Principle allows fairly marked educational inequalities between the weak and the strong provided that such inequalities entail great educational efficiency, which is itself conducive to higher economic growth, which in turn leads to higher incomes for the least well-off.

In other words, in Rawls' view a fair social system is one that offers equal chances of achieving educational success or, in the event of equal qualifications, which offers equal access to better jobs. Then, where two education systems are identical from the point of view of equal opportunities, if we give priority to the social bases of self-respect, the fairer system will be the one showing the least inequalities between individuals, whereas if we give priority to wealth the fairer one may be the most efficient, even if that means favouring the most talented, but only on condition that this greater internal efficiency leads to an improvement in the situation of the least well-off. But in either case a policy of giving priority regardless of the social effects to educational efficiency over educational equity, or to average student performance or to the performance of the elite over either equal educational opportunities, or the standard of the weakest students or the gap between the weakest and the strongest will go against the principles of the Theory of Justice.

Another way of arguing that the Theory of Justice gives priority to equity over efficiency in education would consist in considering that Rawls' first principle, which takes priority over all others, also concerns education. According to this principle, "each person is to have an equal right to the most extensive basic liberty compatible with a similar liberty for others". But education does not provide access only to social positions (through fair equality of opportunity) or to primary social goods (Difference Principle). The distribution of education affects that of liberties in two ways: it is both an instrument of liberty - insofar as a parallel may be drawn between Rawls' concept of liberties and Sen's concept of capabilities (Verhoeven, Orianne \& Dupriez, 2005) - and an instrument of domination. In both cases, equality of liberties can be achieved only to the extent that the inequalities between individuals with regard to the skills most closely related to the use of those liberties (especially the capability of expression) are as reduced as possible (Meuret, 2004). In my view, according to the Theory of Justice this objective should be placed above average proficiency in mathematics.

And yet the tendency among specialists of the education system is for us to give priority to internal efficiency. Among the countries that show equal efficiency, we prefer those where equality of opportunities is the greatest, ${ }^{4}$ but we would be reluctant to approve a country where low efficiency comes with low inequality of performance or opportunities. The reasoning is implicitly economic: you have to produce before being able to redistribute, or you have to be able to cure some before you can cure all, etc. What we fail to see is that education, using the economists' expression, is an illiquid good, which cannot be transferred from one individual to another, and which cannot therefore be redistributed like wealth, even though it strongly affects social position and self-respect. If we think about it, however, we probably have more indications of the 
hierarchizing effects of education than of its social benefits, which are likely but not so easy to pinpoint accurately (Gurgand, 2004; Baudelot \& Leclercq, 2005).

Going along with Rawls' ideas would entail another upheaval in our approach to education. We should concentrate much more on the external effects of education than we do at present. It was enough in the past to believe that opening a school was equivalent to closing a prison. More recently, we were content to believe that education stimulated economic growth. Now that education has become a good coveted by all, because it is thought to open the way to greater well-being, it is clear that the equitable aspect of its distribution has become a major political issue and that the notion of equity brings with it the question of external effects. ${ }^{5}$ From a Rawlsian point of view, the inequalities of education should be checked against fair equality of opportunity and the Difference Principle. From a utilitarian point of view, it must be ensured that distribution contributes towards the maximization of general well-being. It would be wrong in fact to assume that education is bound to have beneficial social effects. There are historical examples on the contrary of education producing tragic effects. The Germans paid a great deal of attention to the role of education during the rise of Nazism. But it would equally be worth examining the role of the French education system (especially its elitist and formalistic aspects) in the emergence of Pétainism and collaboration; after all, Maurice Papon, the so efficient collaborationist was a brilliant product of the education system of the Third Republic.

It is now time for us to see whether in fact a choice has to be made between internal efficiency and equity, giving an outline of how we shall proceed before considering the question from the point of view of different possible definitions of equity and efficiency in education.

\section{Criteria and data: the method}

\section{HOW TO MEASURE EQUITY}

According to the approach adopted by the European Research Group on the Equity of Education Systems - which was worked out in the course of a working group meeting at the SRED (Geneva Educational Research Department) by Norberto Bottani and by Walo Hutmacher (Meuret, 2001) - there are three aspects of the distribution of education that are relevant for gauging the equity of education systems:

- Low proportion of students under the minimum skill threshold: it is fair to expect each generation to equip all members of the next generation with the ability to cope with the fast and complex development of the world they inherit.

- Low educational inequalities between social groups: a lack of connection between social background and educational performance is one aspect of equal opportunities, one of the key aspects of justice in an individualistic society; it encourages an open, efficient and solidary society.

- Moderate inequalities between individuals: educational inequalities between the most and the least educated are not at all natural; according to an argument derived from Rawls' Theory of Justice, they are legitimate only provided that they remain within such limits that they do not detract from social cooperation on an equal footing. 
To these three criteria, which are internal to the education system since they concern goods distributed by the system itself (such as skills and diplomas), may be added an external criterion derived from Rawls: educational inequalities between individuals are legitimate solely on condition not only that they comply with equality of opportunities but also that they are propitious to the long-term expectations of the least well-off, including self-respect (Difference Principle).

From the point of view merely of internal criteria, are these criteria really different?

The answer is "probably", at least according to the findings of the PISA study, that is, if we look at proficiencies acquired by the end of compulsory schooling.

The correlation between the values of the various indicators considered in pairs for the same country lies mostly in the range $0.6-0.7$. This means that these inequalities "go together" to a large extent, but also that the classifications are not quite identical. There are countries where all three types of inequality are either strong (Switzerland, Germany) or weak (Finland, Sweden), but also countries, like Italy, where the standard of the weakest is very low while inequalities between individuals and between social groups are relatively weak; others, like the United Kingdom and Ireland, where inequalities are fairly pronounced but where the weakest are not abandoned; and others still, like Denmark, where social inequalities are weak but where dispersion is high and where many students achieve only low scores (Table 1).

\section{MEASURING EFFICIENCY}

The efficiency of an education system will be estimated here using two indicators calculated on the basis of literacy proficiency as measured by PISA 2000. The first and most commonly used, including in OECD reports, is average score. Another we shall use is the performance of the school elite, based on the value of the ninth decile, that is the score above which the best $10 \%$ of students perform.

It may be objected, of course, that the performance of the elite is not indicative of the overall efficiency of the education system. This argument, however, does not really stand up to scrutiny: the very people in France who criticize the inefficiency of the education system in the United States feel compelled to admit at once that the best American universities are remarkable. In order to counter accusations that standards had fallen in

TABLE 1. Correlation between indicators of the distribution equity of literacy performance (PISA 2000)

Consolidated indicator of social inequality and score dispersion

Consolidated indicator of social inequality and proportion of very weak students

Low dispersion and high value for weakest decile (rankings)

Low dispersion and weak effect of father's occupation

Weak effect of father's occupation and high value for weakest decile

Sources: First two lines: Duru-Bellat, Mons and Suchaut (2004) for all PISA countries. Last three: author's calculations for 13 European countries. 
France, the only way was to show that the standard of performance achieved in the entrance examinations of the top universities (grandes écoles) had not fallen (Thélot et al., 1996). Even the interactions between teachers and students, which favour the best students, show that it is commonly recognized that a "good" teacher and a "good" school are essentially ones which have a few top-notch students. Similarly, if the agreed policy is to concentrate the best students in selected classes, streams or establishments on the grounds that this is good for the country, it is because the efficiency of the education system tends to be gauged by the standard of the elite it produces. If we want to discuss the links between efficiency and equity, however, we have to take account of the criteria actually applied by the parties to the debate.

\section{METHOD}

In order to find out whether in education equity and efficiency compete or complement each other, it is worth looking at national trends and international evaluations. According to national trends, for instance, between 1985 and 1995, the tests undergone by French conscripts show that the opening up of secondary education in the country led to a rise in the average standard, a slight improvement in the performance of the strongest and an even greater improvement in the performance of the weak, in other words to an improvement from the point of view of our three equity criteria and our two efficiency criteria.

International evaluations, on the other hand, indicate three configurations.

(a) In the case of negative correlation between equity and efficiency, in other words if equitable countries are generally inefficient and inequitable countries generally efficient, then a choice has to be made and that choice is a political one. Above, we argued in favour of equity but that does not exclude an alternative choice.

(b) A nil correlation means that both objectives can be achieved at the same time, but that it is also possible to achieve one to the detriment of the other. This is either because some policies achieve both objectives simultaneously while others achieve one to the detriment of the other, or else because the policies adopted pursue the two objectives independently of each other. If so, there are four possible scenarios, which occur with roughly similar frequency: countries that are either equitable and efficient, equitable but inefficient, inequitable but efficient, or inequitable and inefficient. In this case, it is worth examining in particular in what respect the countries that succeed with both objectives differ from those which fail to achieve either.

(c) A positive correlation - where the most efficient countries are also in general the most equitable - shows that the policies or mechanisms which favour one of the goals may also favour the other. In this case, the comparisons show not so much that all policies favourable to equity also favour efficiency and vice versa, but rather that there are policies that favour both and that these are the ones this group of countries has decided to introduce. But the question then arises of whether it is by aiming at efficiency that equity is achieved by rebound or whether it is by seeking equity that efficiency is achieved indirectly. 
It should not be forgotten, however, that no international evaluation can prove that it was not a third set of variables, which happens to be present in the "model" countries and not in the country under consideration, that might explain for instance the simultaneous achievement of both efficiency and equity: in that case what proves a good combination elsewhere might not apply in the home context. Even so, however, it is clear that international comparisons reverse the burden of proof.

DATA

The following analysis is based on the PISA 2000 and 2003 results for OECD countries at a comparable level of development and on the more limited sample of the following countries shown in Table 2.

\section{Is there a need to choose between efficiency and low dispersion of performances?}

Let us see what arguments support either the theory that equity and efficiency compete or the notion that they are complementary:

The arguments in favour of the theory that equity and efficiency compete are as follows:

(1) Education cannot go against the limits imposed by natural abilities.

(2) Egalitarian policies do away with rewards for accomplishment and therefore also with the desire to succeed.

(3) They render the education of all more difficult by admitting unruly pupils in the classrooms and by making classes more heterogeneous. ${ }^{6}$

The arguments in favour of complementarity run as follows:

(1) Raising the standard of the weakest has the effect of reducing dispersion and improving average performance (mathematical effect). This effect will be more marked to the extent that the efficiency-oriented policies work precisely because they improve the performance of the weaker students. ${ }^{7}$

(2) Increasing the pool of students will heighten pressure on the top performers.

(3) The weakness of weak pupils is partly due to a method of teaching that produces this weakness and emphasizes differences. There are policies therefore which will rectify this type of teaching and improve both equity and efficiency. For example, mixed classes benefit the weakest more than they detract from the strong, so that their effect is to raise both the average performance and that of the weakest pupils. To give another example, reducing the pressure of evaluation, according to social psychology, would improve both the efficiency and the equity of education (Toczek \& Martinot, 2004).

In terms of literacy, if efficiency is measured by average performance, international comparisons tend to support the theory of complementarity.

If the countries of Table 2 are ranked by order of efficiency according to average scores and from lowest to highest dispersion, we arrive at a correlation that is weak but still positive, at 0.20 . In other words there is no competition between homogeneity and the 


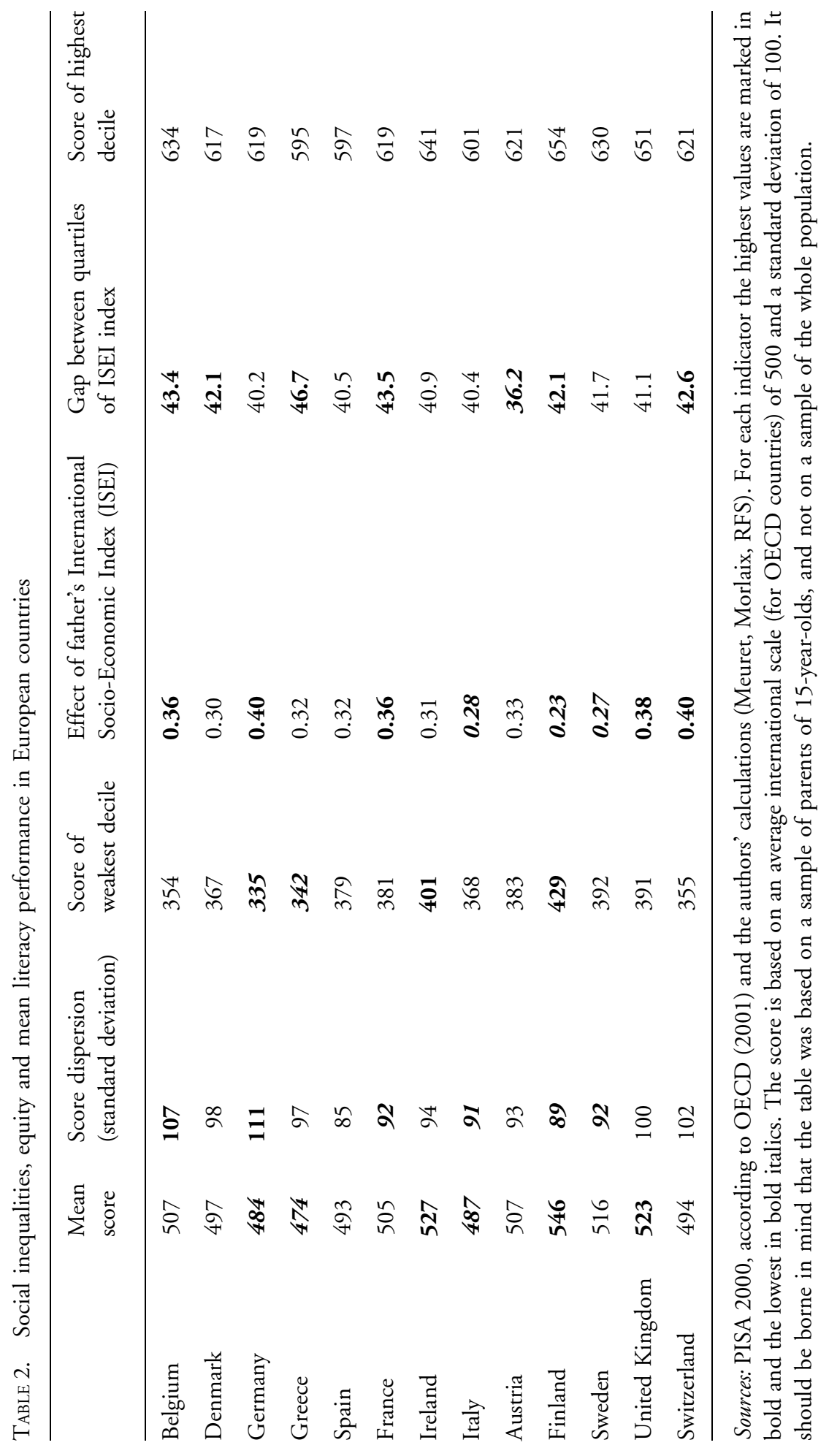


TABLE 3. Correlation between dispersion of student scores and two indices of efficiency in OECD countries ${ }^{a}$

\begin{tabular}{lll}
\hline & $\begin{array}{l}\text { PISA 2000, } \\
\text { Reading }\end{array}$ & $\begin{array}{l}\text { PISA 2003, } \\
\text { Maths }\end{array}$ \\
\hline $\begin{array}{l}\text { Correlation } \\
\text { Standard deviation }- \text { mean score }\end{array}$ & -0.06 & 0.25 \\
Correlation & 0.32 & 0.41 \\
Standard deviation -90 & & \\
\hline
\end{tabular}

${ }^{\mathrm{a}}$ Excluding Mexico and Turkey.

average standard of literacy performance. ${ }^{8}$ This is also reflected in Table 3, which is based on OECD countries at a comparable level of economic development, ${ }^{9}$ since the correlation of values in that case is negative. The correlation $(-0.06)$ is very weak, however, which means that there are also efficient and heterogeneous countries, like the United Kingdom, and others such as Italy and Spain where average performance is weak but dispersion is low. The overall relation, however, does not point to a need to choose between equity and efficiency.

This is less true for mathematics, where a coefficient of 0.25 means that there are efficient and homogeneous countries, but not as many as countries where high average scores come with a degree of dispersion.

And what happens if the standard of the school elite is taken as the criterion of efficiency? It might be the case that the policies are good for the weakest pupils and mathematically improve average performance, but at the expense of the best pupils. Of course, they would lose less than the weakest would gain (otherwise average performance would fall) but they would still lose out. On the other hand, it must be borne in mind that the higher the standard of the elite, the more it will push distribution upwards.

It turns out that there is in fact a correlation between the standard of the strongest (the value of the 90th percentile) and the breadth of dispersion, but what is striking is that this correlation is relatively low. For the countries of Table 2, the figures are +0.16 for the correlation between elite scores and overall score dispersion, -0.13 for the correlation between rankings if countries are ranked according to the highest standard of the elite and the lowest dispersion. Table 3 shows a correlation of 0.3 and 0.4 of values for all comparable OECD countries. While there are some countries with a strong elite obtained at the cost of high dispersion (in terms of reading this applies to New Zealand, the United Kingdom and Australia), there are others which manage to combine a strong elite and low dispersion (as in Finland and Sweden). Nevertheless, there are more countries with a strong elite and high dispersion or with a weak elite and low dispersion than countries where efficiency and equity go together. 
We have arrived at a point where it would be worth investigating the differences between Scandinavian countries and Commonwealth countries.

\section{Is there a need to choose between efficiency and the standard of the weakest?}

Here we have a purely mathematical relation between our two variables. Other things being equal, the higher the standard of the weakest, the higher will be the overall average. But according to the arguments we mentioned above, it might appear that this mathematical relation does not obviate the fact that favouring the weak must mean sacrificing the majority or the elite. This will happen if:

- Policies in favour of the weak are inefficient and divert resources needed by the remainder of students;

- Policies in favour of the weak are efficient for the weak, but drag down the performance of other pupils.

On the other hand, we will have complementarity if:

- Policies in favour of the weak do not detract from other categories;

- Policies in favour of the weak encourage the other categories of students to improve their own performance.

The lesson which emerges from international evaluations, from PISA at any rate, is that efficiency and the standard of the weakest go hand in hand, whether efficiency is measured according to average performance or to the standard of the best pupils (though in the latter case the relation is less marked).

For the countries of Table 2, the correlation between the rankings of countries classified according to average performance and the value of the top decile of performance works out at 0.83 . The correlation between the values of the top and bottom deciles is 0.63 .

For all OECD countries (excluding Mexico and Turkey), the coefficients are given in Table 4.

Of course, this does not mean that all policies in favour of the weak necessarily raise the average standard or the standard of the strongest, but it does mean that such policies do exist and that they represent a clear majority.

It remains to be seen whether such policies are rather efficiency-oriented policies which happen to have been more beneficial to the weak, like the British Literacy Hour according to a recent assessment (Machin \& McNally, 2004), or policies in favour of the weak which simply did not detract from the remainder of students.

TABLE 4. Correlation between the scores of the weakest pupils and two indices of efficiency

\begin{tabular}{lll}
\hline & PISA 2000, Literacy & PISA 2003, Maths \\
\hline Correlation 10 - mean score & 0.91 & 0.96 \\
Correlation 10-90 & 0.66 & 0.90 \\
\hline
\end{tabular}

Source: Author's own calculations. 
In other words, is it better to try to improve average efficiency on the grounds that this will profit the weakest while lowering dispersion, or to try to raise the standard of the weakest in the hope that this will produce a favourable effect on overall performance? Clearly this sort of correlation can be used to support very different policies.

The answer, it appears, would depend on the shape of the correlation. If we draw a graph of the performances of the different deciles, we obtain a set of straight or semistraight lines that are either fan-shaped, funnel-shaped or parallel. The proposals put forward below start from the assumption that a special effort needs to be made for populations for whom the differences between countries are the most marked. This is because if the situation of a population is the same regardless of which country it lives in, it may be assumed that it is little affected by the social or educational environment.

If the graph is funnel-shaped, it will be preferable to opt for policies favouring the weakest.

If the lines are parallel, the best policies will those favouring efficiency in general. If the graph is fan-shaped, we are left with a subsidiary quandary as to whether to opt for equity or for efficiency: policies in favour of the weakest will not have an adverse effect on the standard of the strongest, but it is likely that they will be less efficient, from the point of view of improving average performance, than policies aimed at general efficiency.

For our group of 13 countries, Figure 1 shows the values for the different quantiles $(5,10,25,75,90,95)$ for performance in mathematics in 2003 (OECD, 2004, p. 356). At first sight, the gaps between the curves are constant, with, on closer inspection, a slight funnel-shaped tendency. This tendency is confirmed by the fact that the spread of the distribution of the 5 th percentile (the weakest pupils) in the countries is greater than that of the 95th percentile (118 points compared with 95 for our 13 countries, and 136 compared with 95 for all OECD countries). ${ }^{10}$ The same tendency may be observed for literacy in PISA 2000: among OECD countries, the spread is 106 for the 5th percentile and 68 for the 95 th. $^{11}$

FIGURE 1. Distribution of mathematics proficiency in 13 OECD countries (PISA 2003).

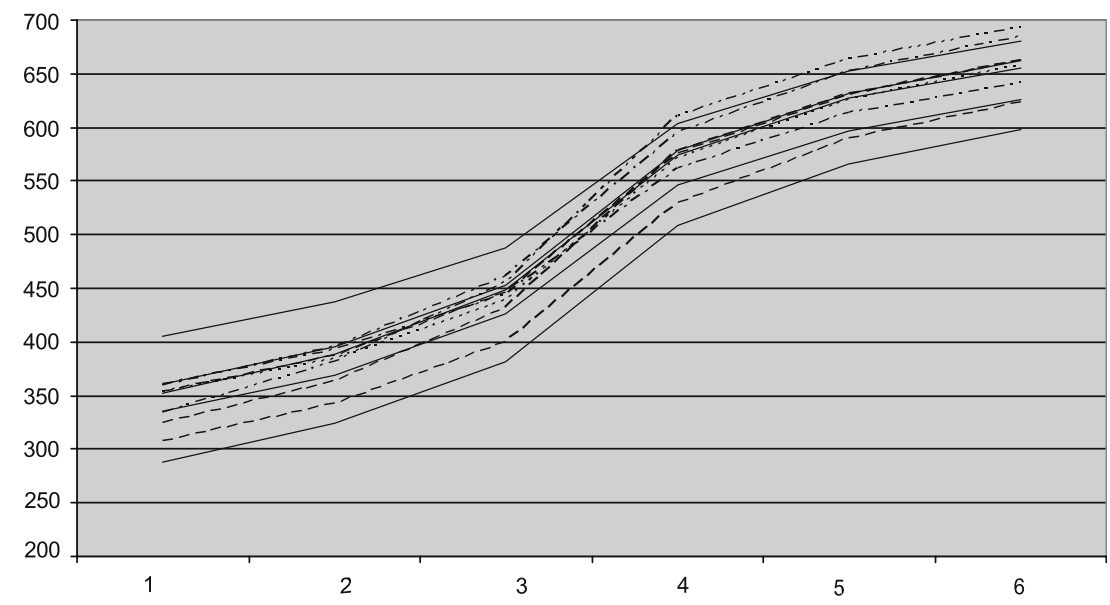

Source: The author, based on OECD, 2004, p. 356. 
FIGURE 2. Spread of reading skills among 15-year-olds in Italy (series 1), Switzerland (series 6), Finland (series 3) and Sweden (series 4).

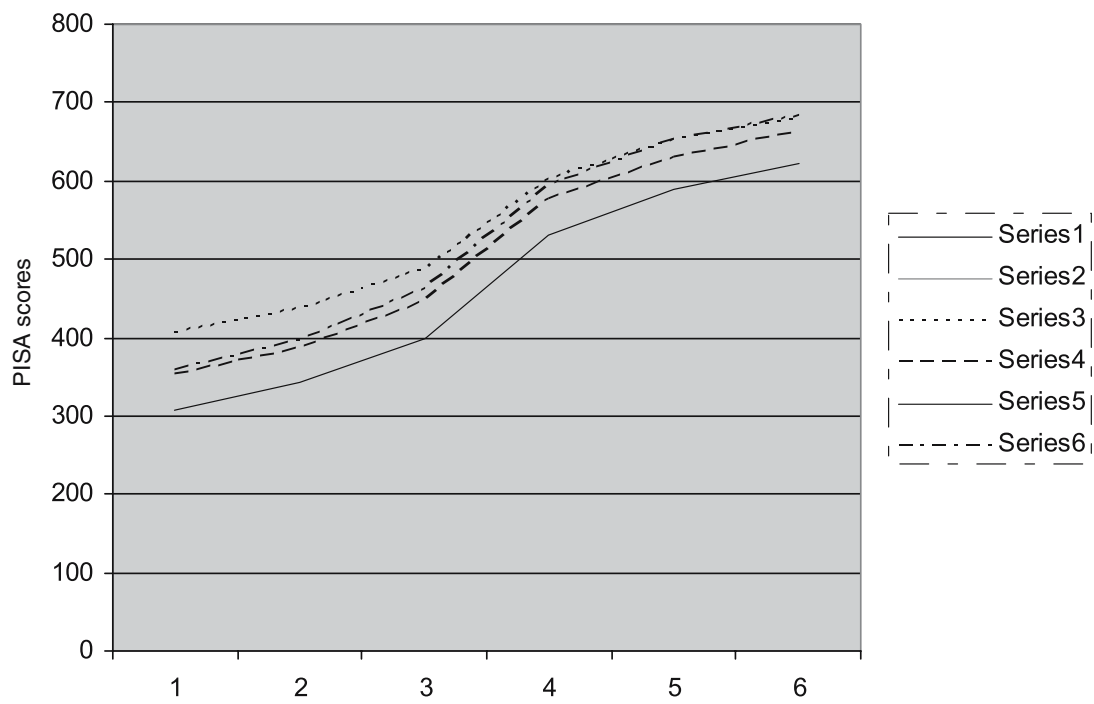

The funnel shape means therefore that generally speaking it is preferable to implement policies aimed at improving the standard of the weakest. This is particularly so in Switzerland, which stands out in mathematics by the weakness of its weak pupils and the strength of its strong pupils: this appears clearly in Figure 2, since the 95th percentile for Switzerland is one of the highest for OECD countries while the 5th percentile is barely above the international value for that percentile (see Figure 2 and OECD, 2004, p. 356). But this is not always the case: in Italy, for instance, it would be preferable to consider a policy aimed at increasing efficiency for pupils at all levels (Figure 2).

Let us take the case of Switzerland and let us imagine that we want to implement a policy that improves the standard of the weakest students.

According to the indications of empirical studies, one should proceed as follows: avoid separating out the weakest pupils, and opt not so much for policies offering them a softer form of teaching but rather to organize teaching that ensures equal requirements and a possible fall-back solution in case that fails.

There are many examples of successful policies that expose the weakest pupils to the same requirements, the same Opportunity To Learn, as other pupils [national curriculum or Literacy Hour in Britain (Machin \& McNally, 2004), unified secondary school and opening up of secondary education in France] and of the failure of policies specifically targeted at those categories [In France: streaming, but also priority education zones (ZEPs) (Meuret, 1999; Kramarz, Benabou \& Prost, 2005) and psycho-pedagogic assistance (Mingat \& Richart, 1991).].

Nathalie Mons, in a recent thesis, has also studied the impact of the organization and structure of education systems on their degrees of efficiency and equity. Her results may be summarized in Table 5 . 


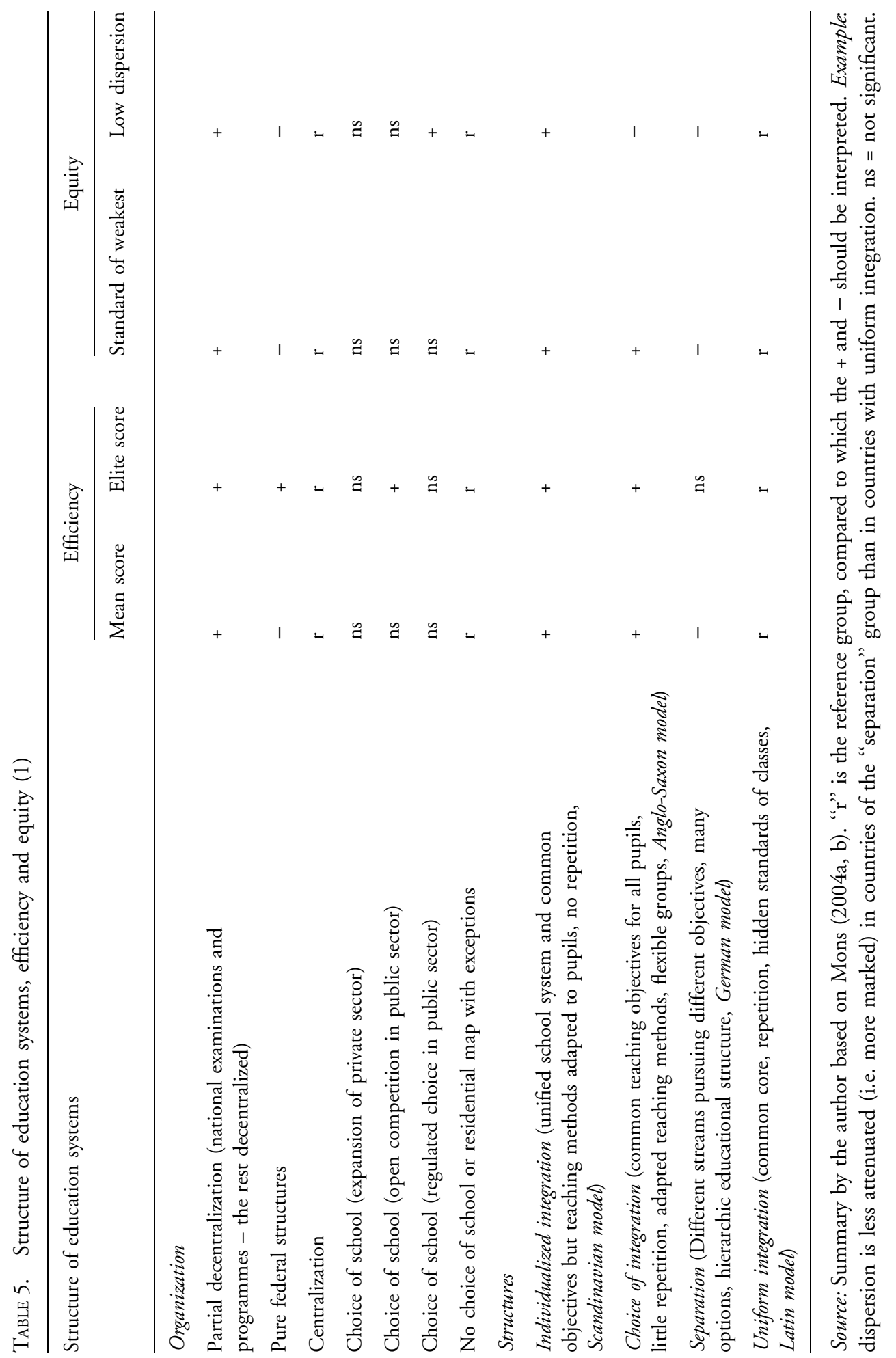


This table, seen from the point of view of our two equity criteria, also shows that equity and efficiency are not contradictory (being supported by the same structures) and highlights the Scandinavian model (partial decentralization, regulated choice and little differentiation in the school system).

Does this mean that this model should be introduced in France or in Switzerland? Perhaps not, but it is probably advisable to avoid shifting our systems any further away from the model, and also to try to understand the underlying reasons why our countries cannot adopt it. The nature of these reasons matters a great deal when it comes to constructing policies.

\section{Is there a need to choose between efficiency and a weak social background effect?}

No one, of course, argues against equal opportunities and in favour of social inequalities. Nevertheless, it may be observed that our societies are prepared to tolerate a considerable degree of social inequality in the school system. This means that those who stand to gain from such an attitude will tend to base it on some plausible justification, whether true or false.

One of these justifications appeals to the notion of liberty (Nozick, 1974): if the wealthy have acquired their wealth without infringing the property rights of others, there is no reason to prevent them from spending their resources on their children's education. Another justification given is based on internal efficiency: according to this, social inequalities are an unfortunate but inevitable consequence of inequalities between individuals, which can be justified by the greater good of all. The last justification is the one derived from Boudon: it is no use reducing social inequalities with respect to education because it does not increase social mobility.

The views in favour of equal opportunities sustained by the Swedish sociologists Jonsson and Ericsson (2000) can be taken as a reply to those three arguments:

- An individualistic society which, in the name of individualism, allows its wealthiest members to deploy their resources limitlessly for the benefit of their descendants will soon end up as a society of castes, families and idle rich, in other words the very opposite of an individualistic society. Equality of opportunities is essential to an open society.

- Equal opportunities make it possible to take advantage of the "reserve of talents" offered by lower-class children and are therefore conducive to economic efficiency and the well-being of all.

- Equal opportunities encourage a sense of solidarity between rich and poor and therefore favour the well-being of the poor through ways other than social mobility.

Clearly, one of these arguments, the second, which is the most concrete and the most immediately verifiable, raises the issue of competition between equity and efficiency. But on what grounds, in theory, can it be argued that equity and efficiency in this context are either in competition or complementary?

The argument whereby efficiency and equal opportunities compete runs as follows:

- In order to assist the children of the underprivileged social classes, help is given to the weak and this detracts from efficiency for the reasons given above. 
- Assisting the children of the underprivileged social classes favours children who have access to less external resources and therefore detracts from the effect of the school system: the best jockeys must ride the best horses.

The arguments in favour of efficiency and equal opportunities being complementary run as follows:

- Helping children of underprivileged backgrounds to succeed opens up the reserve of talents.

- Policies favouring equal opportunities encourage emulation and thence efficiency: to continue with the equine metaphor, the more horses are brought to the starting gate, the better will be the winner's performance.

There are examples of national developments that favour both equal opportunities and efficiency [e.g. France, it has been alleged, during the ten glorious years of the start-up of its education system (1985-1995); Sweden and the Netherlands, according to Shavit and Blossfeld (1993)].

What do international comparisons tell us?

For the countries of Table 2, i.e. in terms of literacy according to PISA 2000, there is a weak but positive correlation between a high average performance and a weak effect of the father's occupation on school performance (ranking correlation: 0.23 ). On the other hand, the correlation is even smaller but negative between the standard of the elite and a weak effect of the father's occupation $(-0.06)$.

For all OECD countries taken together (except Turkey and Mexico), we obtain Table 6 as shown below.

Where literacy is concerned, the better the average performance of a country's students, the weaker is the effect on the performance of social background: this points rather to a complementary relation between efficiency and equity. On the other hand this is the case neither in mathematics, nor - and this applies to both subjects - whenever the efficiency of a school system is measured by the standard of the school elite. The coefficients, however, are small. Many cases may be observed, for instance in mathematics in 2003, of education systems that are neither egalitarian nor efficient (United States, Hungary), not egalitarian but efficient (Belgium), both egalitarian and efficient (Republic of Korea, Canada, Finland), or egalitarian and inefficient (Italy, Portugal).

TABLE 6. Correlation between social inequalities and standard of performance at the end of compulsory schooling in OECD countries

Influence of parents' occupation on performance in:

Literacy (2000) Mathematics (2003)

\begin{tabular}{lrr}
\hline Mean score & -0.20 & 0.12 \\
Score above which $10 \%$ of students are situated & 0.10 & 0.24
\end{tabular}

Interpretation: a negative correlation means that the higher the score, the weaker the influence, so that efficiency and equity are therefore complementary or compatible. 
Trying to reduce the influence of social background does not, in other words, necessarily entail sacrificing either the average standard or that of the elite (in Canada, in Finland or in the Republic of Korea the elite is very strong and social inequalities are very weak). It is also true, however, not everywhere but more often than not, that the standard of the elite competes with the goal of weak social inequality.

According to the Rawlsian analysis we outlined above, we should in this case give preference to reducing social inequalities. On the other hand, in view of the fact that some countries succeed in making these objectives compatible, and that there are strong arguments in favour of preferring equal opportunities to the standard of the elite, those countries which do give priority to the standard of the elite must at least justify this policy by the external side-effects this produces on the expectations or the well-being of the weakest.

The most productive approach is to observe which policies and mechanisms are linked both to efficiency and to equity. This was the method adopted by Duru-Bellat, Mons and Suchaut (2004) and again by Mons (2004), whose work leads us to Table 7 given below.

In these two areas, the policies aimed at giving preference either to equal opportunities, to the standard of the weakest or to homogeneous performances differ on one point only: opting for centralization rather than partial decentralization. From a Rawlsian point of view, priority should be given to equal opportunities, which would mean opting for centralization, except if an impressive series of conditions apply. Provided that internal efficiency leads to higher economic growth, provided that higher growth leads to more independent forms of work and to less impersonal forms of labour, provided that it increases the likelihood of finding a rewarding occupation, even for the least well-off, maybe Rawls himself would approve the alternative solution.

\section{Internal equity and external equity ${ }^{12}$}

The equity versus efficiency debate is further complicated by the fact that an inefficient education system may, owing to its very inefficiency, produce negative effects on equity in society: if the system does not turn out enough highly qualified youngsters, for instance, it will lead to the best qualified receiving a scarcity premium.

A further complication stems from the observation that a third variable (the social relevance of transmitted skills) may have an opposite effect on each of the two aspects. It could be argued that the less transmitted skills are relevant from a social point of view, the less efficient the system will be in transmitting those skills (pupils have little incentive to work), but it might also turn out inegalitarian in that respect (insofar as the rich will be less willing to commit resources to ensuring that their children learn better), without preventing unequal school careers (insofar as very unequal careers are altogether compatible with poor and little dispersed skills), while at the same time favouring an inequitable society (insofar as positions are then attributed according to mechanisms which are even more propitious than the school system to social reproduction).

This is a situation which we might describe as the Italian vicious circle: education produces a low return; schooling opportunities are poor; inequalities of skills among 


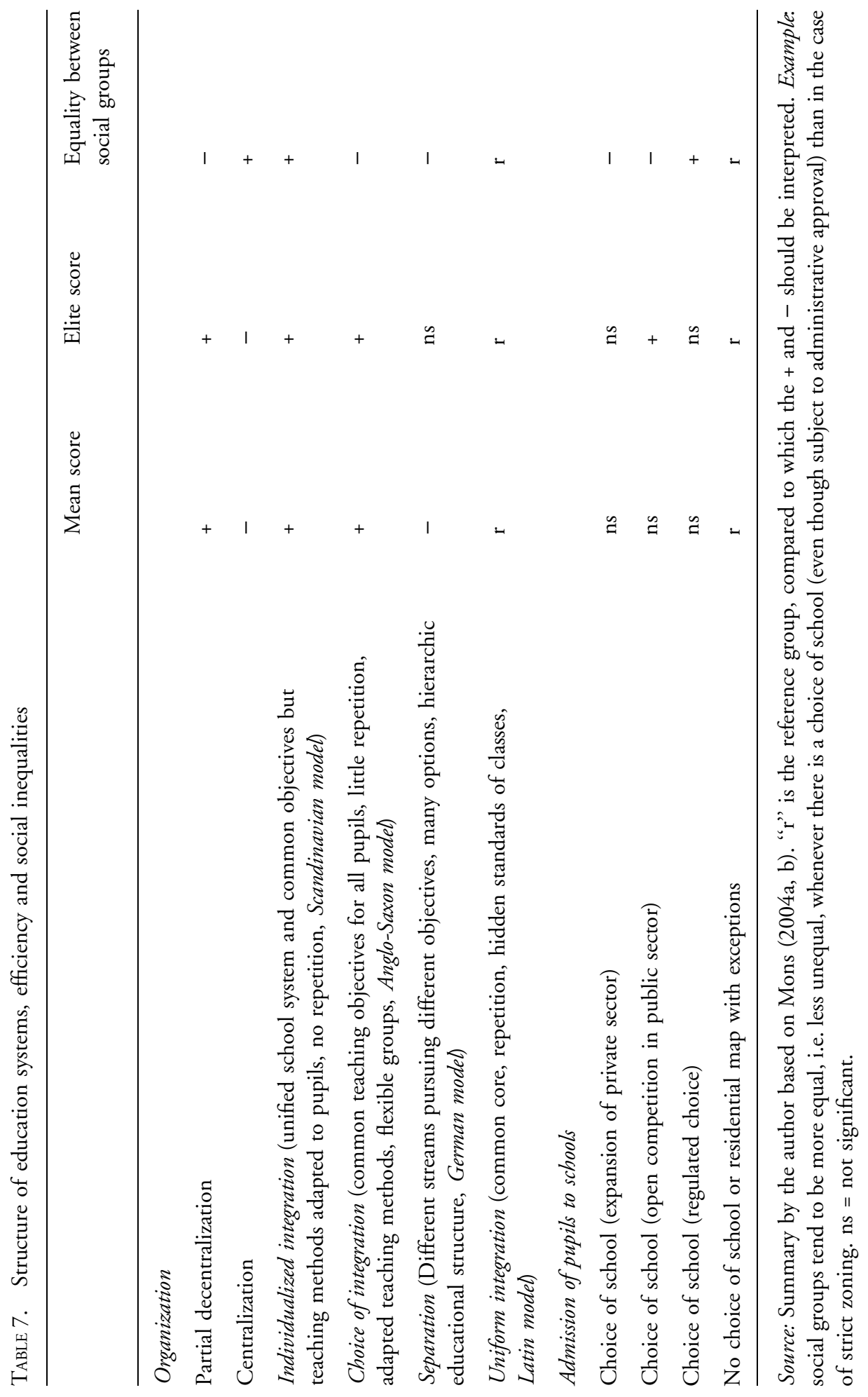


15-year-olds - among both individuals and social groups - are low but the average standard of performance and the standard of the elite are equally low, which does not prevent strong social career inequalities, accentuated by the fact that the offspring of the poor will steer clear of what they consider unprofitable higher studies.

This Italian vicious circle may be set against a "Swedish virtuous circle", which, apart from being conducive to better efficiency and equity, both internal and external, is propitious to the well-being of pupils. The virtuous circle works as follows:

(Low proportion of least well-off and low income inequalities $\rightarrow$ few differences of occupational aspirations based on students' social background) + (a school system that aims to enable all students to succeed (comprehensiveness, lack of segregation, long basic schooling)) $\rightarrow$ (high internal efficiency despite weak economic incentives) + (social equity (low social inequalities of school careers and performances) $)+$ (students' well-being) + (strong feeling of justice among students) $\rightarrow$ (positive social attitudes (mixing of best educated and poorest students, frequent expressions of solidarity, high degree of tolerance and trust in the country's institutions) $) \rightarrow$ (acceptance of an egalitarian social model) $\rightarrow$ (low proportion of poor people and limited income inequalities).

This virtuous circle, which was deduced from a study of Sweden's position in the set of indicators produced by the European Research Group on the Equity of Educational Systems, contradicts two major arguments which underlie the views that efficiency and equity in education are opposed to each other: no efficiency without hierarchy, no efficiency without pain.

1. No efficiency without hierarchy: this refers to the hierarchy of the school system (implying a need for marking, the threat of repetition or transfer to a less prestigious stream in order to make students work - to which the social psychologists reply that internal motivations carry more weight than external motivations) and the social hierarchy, insofar as individuals compete educationally in order to climb the social ladder and educational institutions compete in order to offer them the ability to do so. It appears that individuals, quite on the contrary, work better and are happier in school when they are not set against each other and when they are encouraged instead to improve together (Meuret \& Marivain, 1997; Toczek \& Martinot, 2004);

2. No efficiency without pain: according to this view, not only is success achievable at school only through the pain of effort, but positive social attitudes can be obtained only by controlling natural impulses. ${ }^{13}$ Similarly, still according to the same line of argument, the acceptance of an egalitarian social model will depend entirely on "virtuous" citizens, whose drive to stand out has been repressed and whose wish to succeed has been anaesthetized, whether at school or in daily life. This republican approach to equality as a virtue (Montesquieu) can only lead to the emergence of a virtuous elite, which defeats the purpose. Quite on the contrary, it is possible to read the reconciliation of satisfaction, equity and efficiency in Rawls' assertion (1997, para. 79, p. 567) to the effect that if individuals can exert their own strengths in all security, they are more prepared to appreciate the qualities of others, especially if their qualities fit into a lifestyle accepted by all. 
If we go back to our initial question, namely: "Is it not better to have an efficient education system combined with a good Welfare State rather than a fair but inefficient education system?", the Swedish case appears to tell us that efficiency, equity of the educational system and the quality of the Welfare State are not only compatible but in this case even reinforce each other.

\section{Conclusion}

According to some criteria, the most efficient countries are also the most equitable, which means that most conditions of efficiency are also favourable to equity. This is so in particular when the criterion for equity is taken as the standard of the weakest. In this case, the only question is whether it is preferable, in order to improve both, to conduct policies in favour of the weakest or in favour of all students. In any given country, we found, it is better to target policies at a particular category if that category is the country's distinguishing feature.

But it does happen that equity and efficiency compete. This will occur especially if we define the efficiency of a system according to the standard of the elite and its equity according to the degree of equality between social groups. The correlation coefficients are low, however, which indicates that there may be configurations that are favourable to both. Such configurations, it would appear, include social conditions external to the education system, as illustrated by the Swedish model. Nevertheless, if we have to make a choice, we feel, in the light of a line of argument derived from the Rawls' Theory of Justice, that, in view of the particular nature of the "education" good, priority must be given to equal opportunities over internal efficiency.

\section{Notes}

1. This text is the enlarged version of a talk given at a meeting held in May 2005 by the SRED (Educational Research Department of the Canton of Geneva) to honour its director, Norberto Bottani, on the occasion of his retirement. A very similar version appears in the collection of tributes published by the SRED on that occasion.

2. European Research Group on Equity of Education Systems: Baye, Demeuse, Straeten (Liège), Meuret, Morlaix (Dijon), Tiana (Madrid), Benadusi (Rome), Gorard, Smith (York), with Bottani, Hutmacher (Geneva).

3. This may happen, however: Philippe Raynaud, for instance, places reward for merit above all other equity criteria (see the minutes of a discussion between that author and P. Rayou and myself, in Le Monde de l'éducation, May 2004).

4. For example: "It is clear that the trade-off between efficiency and equity (in the sense of the dispersion of educational performance) allows for many combinations [...] although in general an education system favouring efficiency but without overlooking equity tends to be preferred" (Suchaut, 1997, p. 20).

5. This idea is probably confirmed by the recent riots in the French suburbs, one feature of which was the burning of schools. It is hard to pretend that classroom humiliations and the 
difficulties encountered when it comes to making diplomas pay were not to some extent to blame.

6. According to the report of the Fauroux Commission (1996): "In many schools we find children who are clearly hostile to the acquisition of abstract skills and who are at a standstill without any gain to themselves in classes which are slowed down by their presence" (p. 23).

7. For example, Grisay (1997) points out that the differences between secondary schools in France are based chiefly on the weakest students.

8. Duru-Bellat, Mons and Suchaut (2004) found a more marked relation of the same kind across all PISA+ countries, i.e. including other developed countries and a few developing ones.

9. OECD countries except Mexico and Turkey.

10. The value of the 5 th percentile ranges from 270 (Turkey) to 406 (Finland), and that of the 95th from 598 (Greece) to 693 (Belgium). OECD, 2004, p. 356.

11. The value of the 5 th percentile ranges from 284 (Germany, Mexico) to 390 (Finland), and that of the 95th from 625 (Greece) to 693 (New Zealand). OECD, 2001, p. 253.

12. This theme really deserves much more thorough treatment than the introductory outline we are devoting to it in this paper.

13. "Discipline is in itself an educational factor: there are essential elements in moral character for which it is indispensable. It is through discipline alone that we can teach children to moderate their desires, to limit their desires of all kinds, and to restrict - and thereby define - the goals of their activity" (Durkheim, Moral education).

\section{References and bibliography}

Baudelot, C.; Leclercq, J.F. 2005. Les effets de l'éducation [The effects of education]. Paris: La Documentation française. (Rapport pour le PIREF)

Duru-Bellat, M. 2002. Les inégalitiés sociales à l'école [Social inequalities in schools]. Paris: PUF. Duru-Bellat, M.; Mons, N.; Suchaut, B. 2004. Caractéristiques des systèmes éducatifs et compétences des jeunes à 15 ans: l'éclairage des comparaisons entre pays [Characteristics of education systems and the skills of 15-year-olds in the light of comparisons between countries]. Cahiers de l'IREDU (Dijon), no. 66.

Fauroux, R. 1996. Pour l'école [For schooling]. Paris: La Documentation Française.

GERESE 2003. L'équité des systèmes éducatifs européens: un ensemble d'indicateurs [Equity in European education systems: a set of indicators]. Liège: Service de pédagogie expérimentale.

GERESE 2005. L'équité des systèmes éducatifs européens, un ensemble d'indicateurs [The equity of European education systems - a set of indicators]. Brussels: European Commission. 152 p.

Grisay, A. 1997. Evolution des acquis cognitifs et socio-affectifs au cours des années de collège [Development of cognitive and socio-affective skills during secondary school]. Paris: MENDEP. (Dossiers éducation et formations, no 88.)

Gurgand, M. 2004. Économie de l'éducation [The economics of education]. Paris: La découverte. Hirschman, A.O. 1991. Deux siècles de rhétorique réactionnaire [Two centuries of reactionary rhetoric]. Paris: Fayard.

Jonsson, J.O.; Ericsson, R. 2000. Understanding educational inequality: the Swedish experience. L'année sociologique (Paris), vol. 50, no. 2.

Kramarz, F.; Benabou, R.; Prost, C. 2005. La politique ZEP, quels moyens pour quels résultats? [The policy of Priority Education Zones—resources and results]. Économie et statistiques, no. 380. <http://www.insee.fr/fr/home/home_page.asp>. 
Machin, S.; McNally, S. 2004. The literacy hour. Bonn, Germany: Institute for the Study of Labour (IZA) (Discussion paper, 1005).

Meuret, D., ed. 1999. La Justice du système éducatif [Equity of the educational system]. Brussels: de Boeck, 248 p.

Meuret, D. 2001a. A system of equity indicators for educational systems. In: Bottani, N.; Cochran, D.; Hutmacher, W., eds. In pursuit of equity in education, pp. 133-164. Dordrecht, Netherlands: Kluwer Academic Publishers.

Meuret, D. 2001b. School equity according to the theories of justice. In: Bottani, N.; Cochran, D.; Hutmacher, W. eds. In pursuit of equity in education, p. 388. Dordrecht, Netherlands: Kluwer Academic Publishers.

Meuret, D. 2004. Mesurer l'équité des systèmes éducatifs, pourquoi? comment? [Measuring the equity of educational systems. Why? How?]. In: École Publique, quel contrat social? L'éducateur (Martigny, Switzerland), no. 8, September. (Supplement to the Revue du Syndicat des Enseignants Romands.).

Meuret, D.; Marivain, T. 1997. Inégalités de bien-être au collège [Inequalities of well-being in secondary schools]. Paris: MEN-DEP. [Dossiers Éducation et Formations, no. 89.]

Mingat, A.; Richard, M. 1991. Evaluation des activités de rééducation GAPP à l'école primaire [Evaluation of the GAPP re-education activities at primary school]. Cahiers de l'IREDU (Dijon), no. 49.

Mons, N. 2004a. De l'école unifiée aux écoles plurielles: évaluation internationale des politiques de differenciation et de diversification de l'offre scolaire [From uniformity to diversity in schooling - international evaluation of the differentiation and diversification of schooling]. [Thèse pour le doctorat en sciences de l'éducation, Université de Bourgogne.].

Mons N. 2004b. De l'école unifiée aux écoles plurielles: évaluation internationale des politiques de différenciation et de diversification de l'offre scolaire [From uniformity to diversity in schooling - international evaluation of the differentiation and diversification of schooling]. [Thèse pour le doctorate en sciences de l'éducation, Université de Bourgogne.].

Nozick, R. 1974. Anarchy, State and Utopia. New York: Basic Books.

Organization for Economic Co-operation and Development. 2001. Knowledge and skills for life: first results from PISA 2000. Paris: OECD.

Organization for Economic Co-operation and Development. 2004. Learning for tomorrow's world: first results of PISA 2003. Paris: OECD.

Rawls, J. 1971. A theory of justice. Cambridge, MA: Harvard University.

Shavit, Y.; Blosseld, H.P., eds. 1993. Persistent inequalities: changing educational attainment in thirteen countries. Boulder, CO: Westview Press.

Suchaut, B. 1997. Evaluation d'un dispositif lecture au CP [Assessment of a pre-school reading system]. Dijon: IREDU. (Rapport de recherche)

Thélot, C., et al. 1996. L'évolution des compétences scolaires des meilleurs élèves depuis 40 ans [Changes in the educational skills of the best pupils over the last 40 years]. Paris: Ministère de l'éducation nationale, Direction de l'Evaluation et de la Prospective. (Dossiers éducation et formations, no 69.)

Toczek, M.C.; Martinot, D. 2004. Le défi éducatif [The educational challenge]. Paris: Armand Colin.

Van Parijs, P. 1995. Real freedom for all. New York: Oxford University Press.

Verhoeven, M.; Orianne, J.F.; Dupriez, C. 2005. Vers des politiques d'éducation capabilisantes? [Towards empowering educational policies]. Louvain, Belgium: GIRSEF-UCL. (Cahiers de la recherche en éducation, no. 47.) 